\title{
Experimental research in mechanic's field of control for further innovation in the hydraulic and electronic operated injection system
}

\author{
Iosif Ferențị ${ }^{1, *}$, Dan Opruța $^{2}$, and Doru Băldean ${ }^{3}$ \\ ${ }^{1}$ InterCars, Automotive Engineering Department, 400228 Corneliu Coposu Street, Cluj-Napoca, Romania \\ ${ }^{2}$ Technical University of Cluj-Napoca, Mechanical Engineering Department, 400641 Muncii Bvd 103-105, Cluj-Napoca, Romania \\ ${ }^{3}$ Technical University of Cluj-Napoca, Automotive and Transportation Department, 400641 Muncii Bvd 103-105, Cluj-Napoca, Romania
}

\begin{abstract}
In the present research paper is detailed an experimental work concerning Engine Control Unit (ECU) in order to trace predictive trend-lines regarding operational parameters such as ignition timing, fuel supply, injection duty, at more than ten engine speed regimes in the case of a powertrain for motor-sport competition, with distinct air pressures, injector status and spark advances. An experimental study of real values and trend-lines as well as actuator's output data was realized in order to point out electronic control unit's functional characteristics and to redefine the economic field with optimal combustion pressure, efficient mixture formation/burning and diminished emissions as a consequence of the proper measures. Air intake pressure influences the fundamental conditions for intake charge definition and for lambda level even prior to engine cycle beginning in the powertrain with port fuel injection (PFI). Lambda value expresses the operational quality in relation with the excess air intake compared to the minimal amount necessary for a complete combustion of fuel jet charge.
\end{abstract}

\section{Introduction}

In the recent decades, the injection systems for spark ignited engines have been optimized for different types of applications and configured for automotive field and industrial engines, but to increase output torque and power when downsizing it must be even more accurately tested and electronically regulated. Performances of fuel supply system are to be evaluated and actuated in the perspective of latest results in electro-hydraulic management and Computational Fluid Dynamics-CFD [1-5].

Smart functions regarding fuel supply for automotive powertrains and industry motor-generator equipment brings benefits towards energy economy and performance output. Digital management of internal combustion engines leads to accurate mapping for different work strategies to increase output specs [4-7].

Achievements in technological field contribute to the developing and exploiting port fuel injection in order to increase engine performances and energy efficiency, as well as to reduce mechanical complexity, duration of delays and pollution levels [5].

The stress is to search for perfect response in particular situations and for that engineers and technicians create various scenarios and maps. Research is conducted with accurate procedures based on mathematical models and graphic representations to increase precision in computer aided testing and electromechanical control of injection systems, specifically in the case of a motor-sport engine with some extreme stresses due to the very high speeds, forces and torques.

Fuel injection systems with spark ignition consist in the following: transducers assembly, electronic control unit (ECU) and actuators.

Practical research and experimentation in the field of the fuel supply systems, regarding working variables, actual values, digital programs and electronic map index [5-7] are studied and stored to improve definition of the economic operational range in particular ECU configuration for rally car application.

The purpose of the study is to highlight the relation between the ignition control and the software chart of hydraulic management in order to determine the trendlines of the values recorded from ECU. Secondary objectives of the study are: research of fuel injector duty, intake pressure in manifold, auxiliary duty of ECU and ignition timing versus engine speed.

\section{Research methodology}

Developing the applied study (in the field of electric and hydraulic control of the injection system with application and outcomes in mechanics and automotive engineering for the rally car Mitsubishi Evolution) was based on the specific equipped and configured hardware components and digital functions, working together according to predefined methodology. This allowed a specific method application of close analyze through practical testing as

\footnotetext{
* Corresponding author: doru.baldean@auto.utcluj.ro
} 
well as trend-line representation. Recording the actual values and the functional testing results of the internal combustion engine (ICE), on car's powertrain is presented in a kinetic chain order in figure 1. Injection and ignition elements (valves and electric components) are closely controlled by the ECU via specific connectors, on the basis of specific signals received from input devices. Mechanical control is realized by the first command to the last element in the chain with an electrohydraulic interface. How all these groups interact is the objective of the study.

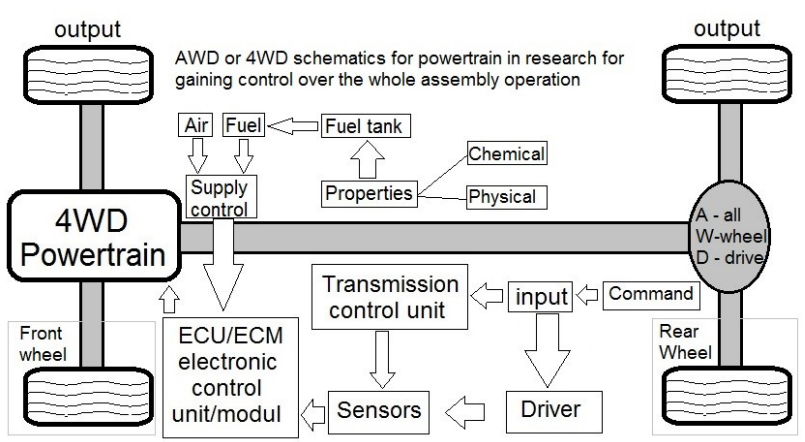

Fig. 1. Schematics of the control in hydraulic system tested.

The methodology of the study (Fig. 2) outlining the aspects of each significant characteristic on the powertrain shows how may be classified all the experimental values.

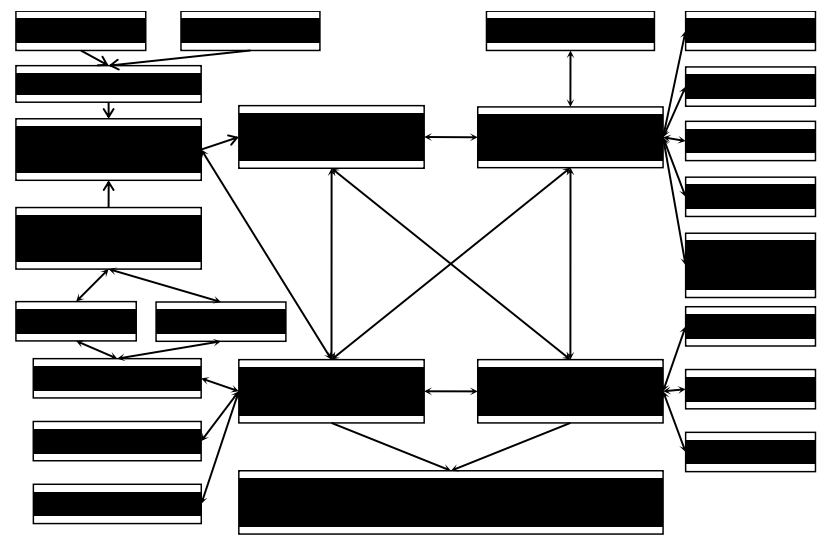

Fig. 2. Methodology of digital control in injection test system.

Methodological scheme provides the sequences and the aspects that must be studied and performed in order to achieve the results of testing and optimizing the injection control system. The hydraulic fuel supply system is partitioned in low and high pressure branches.

The ICE installed on the powertrain is started, wormed up to the operational temperature and prepared for testing at the beginning of the recording phase in practical study (Fig. 3). The blue vertical line on the screen is placed right 24 minutes after start.

Actual values are considered in figure 4, such as intake pressure, throttle angle, injector duty and ignition advance angle.

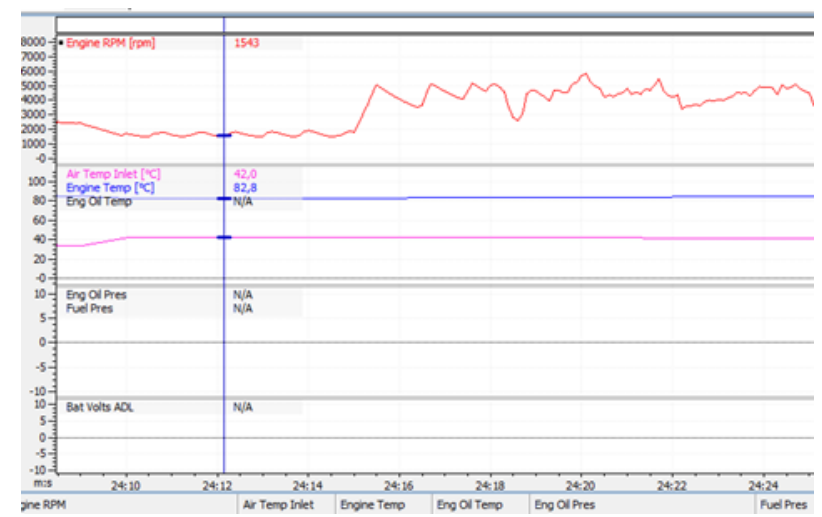

Fig. 3. ECU graph capture with real values in applied testing.

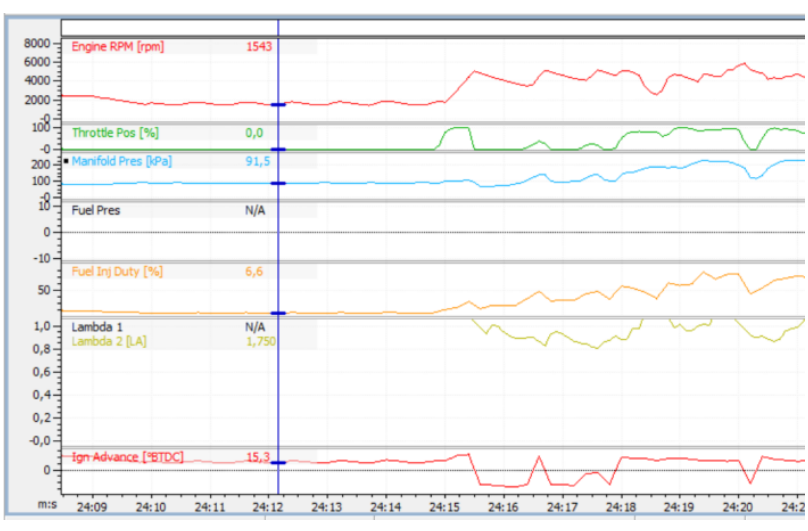

Fig. 4. Applied test measurement of fuel injection duty control.

\section{Mathematical models}

An important parameter that is considered and outlined for a better understanding of electro-hydraulic consideration consists in fuel injection duty versus throttle position, as a ratio from whole amount of sprayed fuel in various operational regimes, as shown by equation:

$$
F_{i d}=1.2 \cdot 10^{3} \cdot x+7.15,[\%]
$$

Lambda coefficient, expressing the excess air in relation to the minimal air amount versus throttle position angle is shown by the formula:

$$
L_{\lambda}=-0.6 \cdot 10^{3} \cdot x+1.7494,[\%]
$$

\section{Experimental testing results}

The engine was properly equipped and calibrated for practical testing, warmed up, technically inspected and actual values were recorded, shown in figures 5-20. These recordings allowed actual data research and trendline representation. 


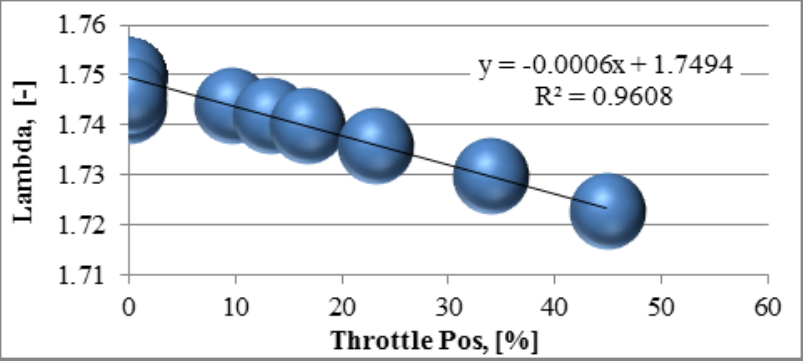

Fig. 5. Lambda coefficient versus throttle position.

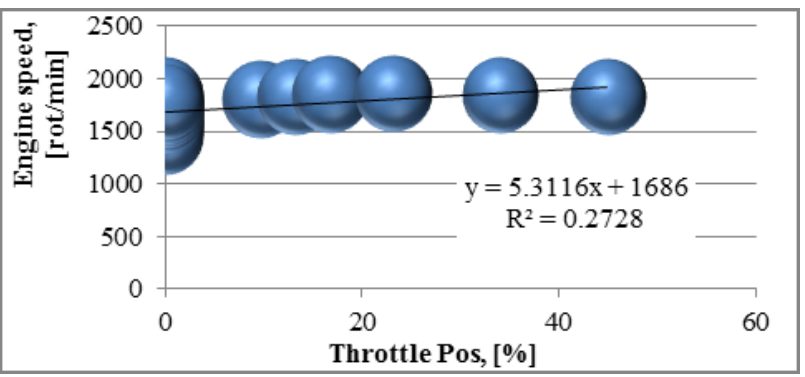

Fig. 6. Engine speed versus throttle position.

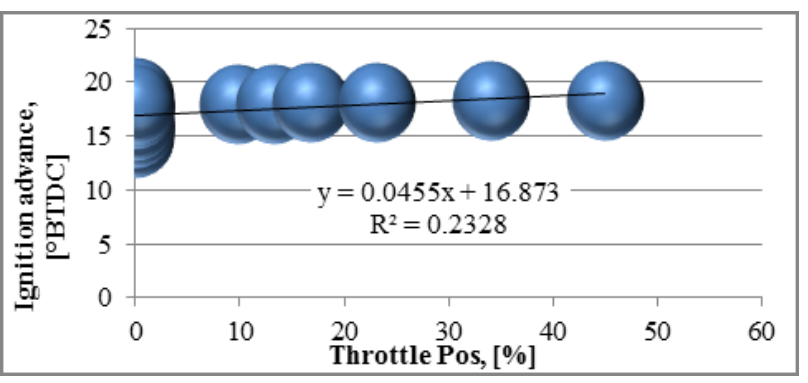

Fig. 7. Ignition advance versus throttle position.

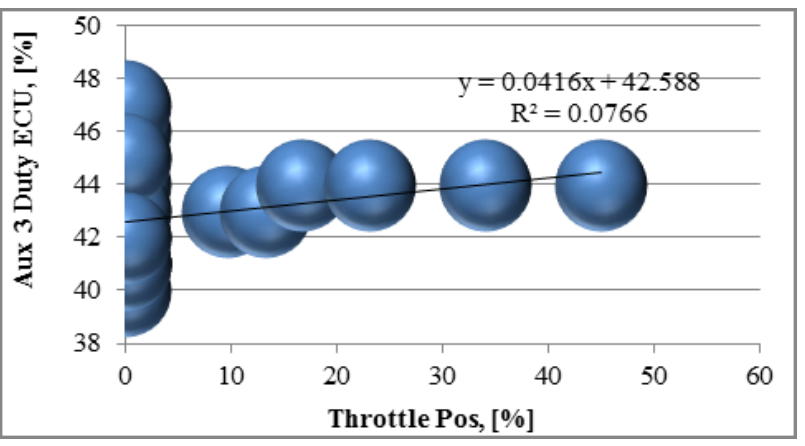

Fig. 8. ECU - electronic control unit auxiliary duty versus throttle position.

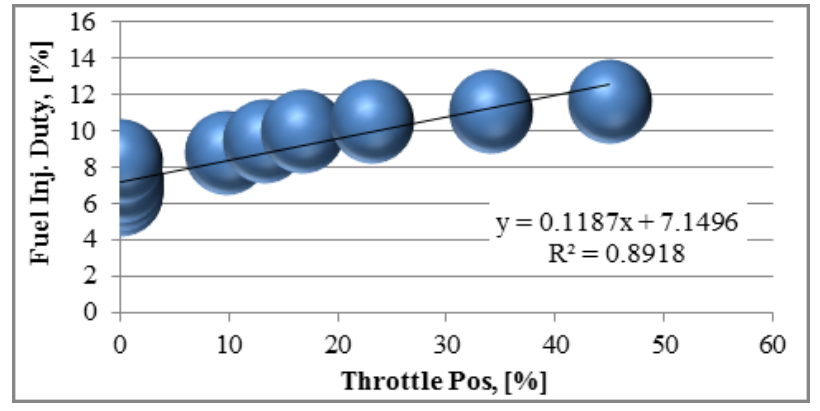

Fig. 9. Fuel injection duty versus throttle position.

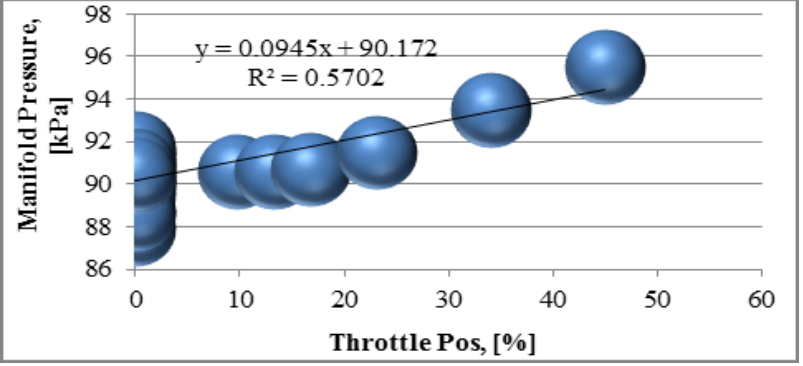

Fig. 10. Intake manifold pressure versus throttle position.

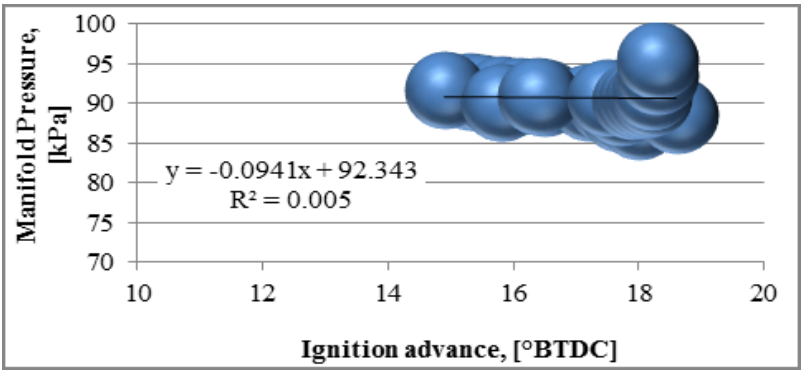

Fig. 11. Air intake manifold pressure versus ignition advance.

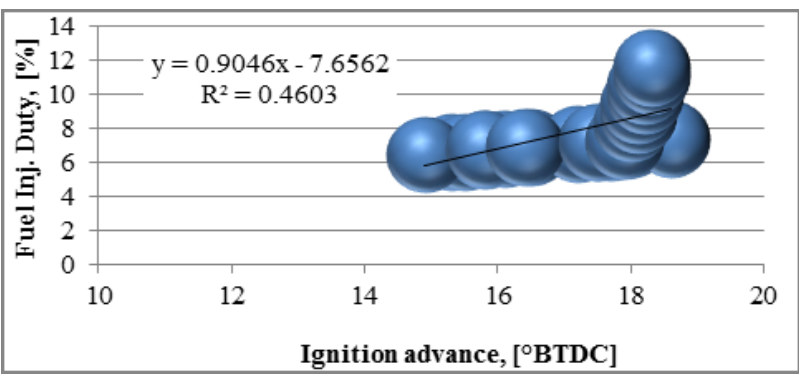

Fig. 12. Fuel injection duty versus ignition advance.

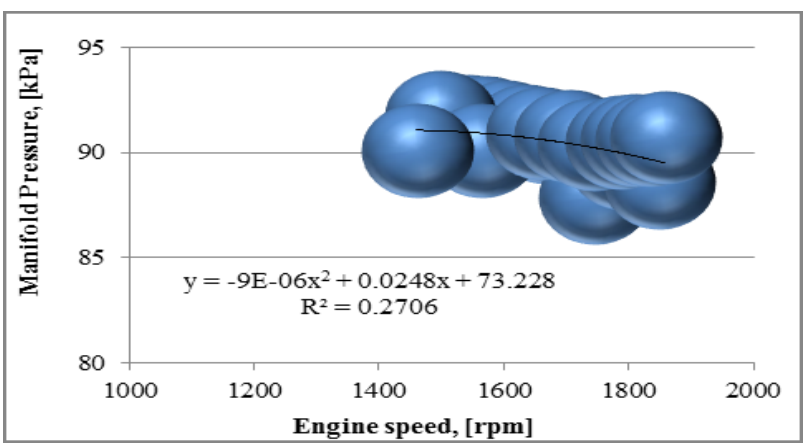

Fig. 13. Air intake pressure in the engine's intake manifold versus engine speed.

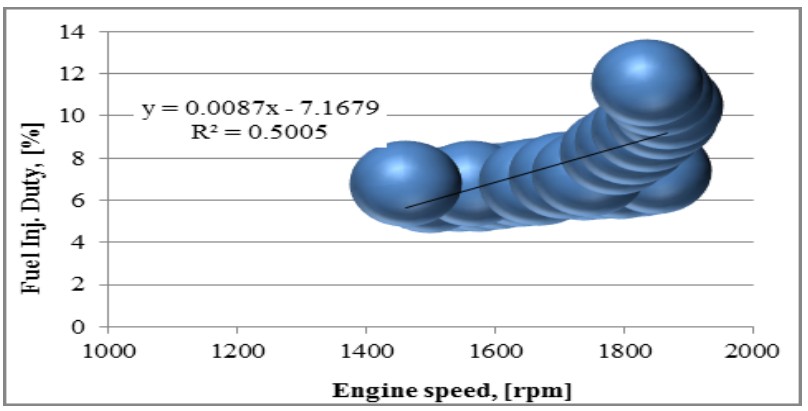

Fig. 14. Fuel injection duty in relation to engine speed. 


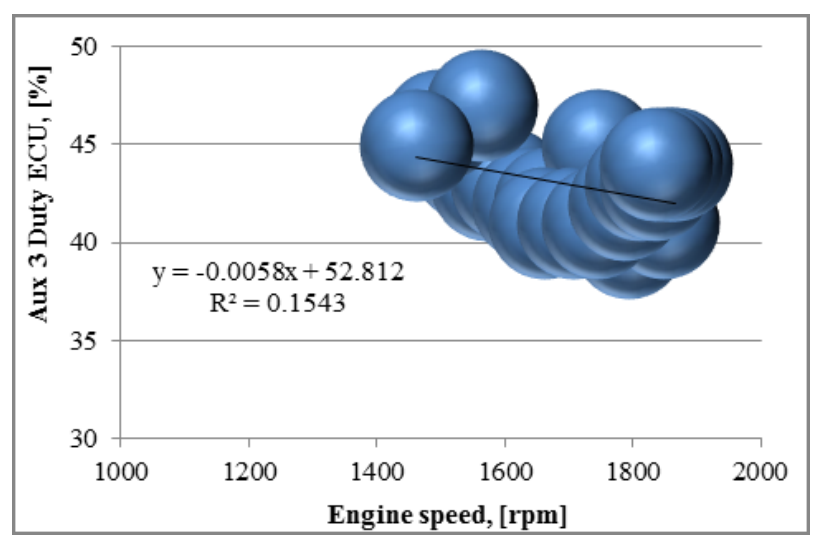

Fig. 15. ECU auxiliary duty versus engine speed.

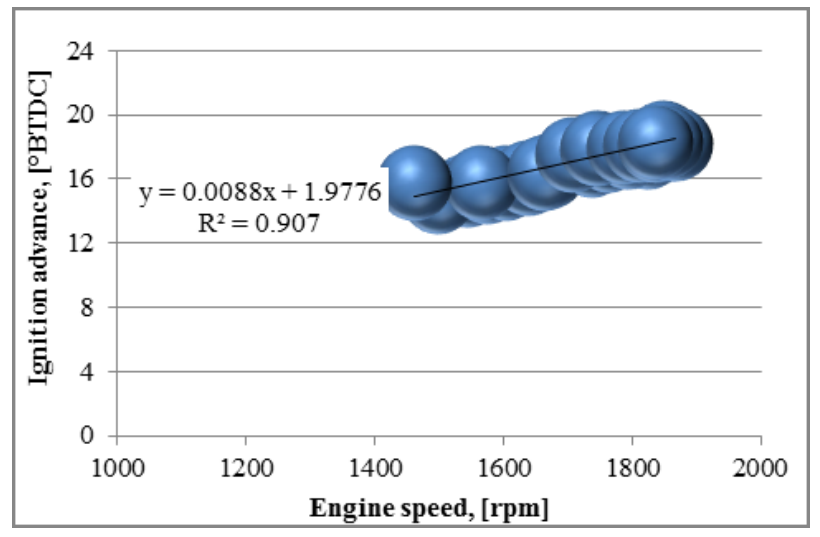

Fig. 16. Ignition advance in relation to the engine speed.

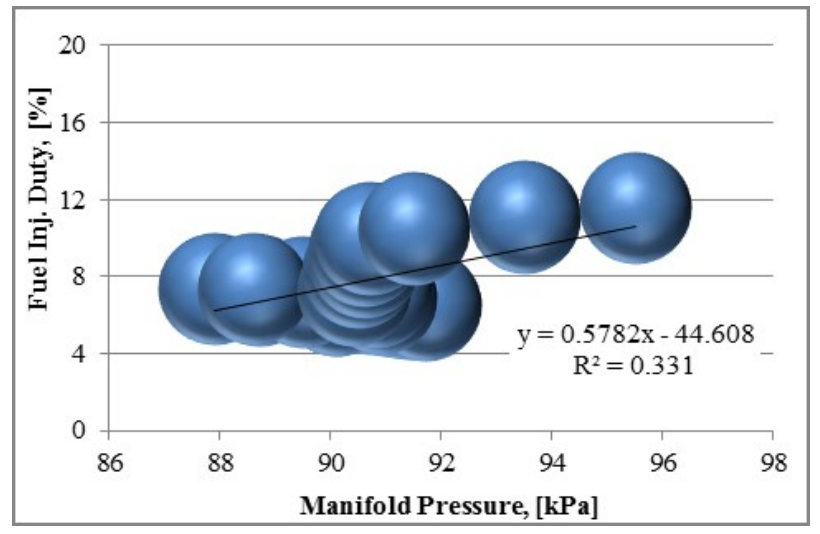

Fig. 17. Fuel injection duty in relation to the air pressure.

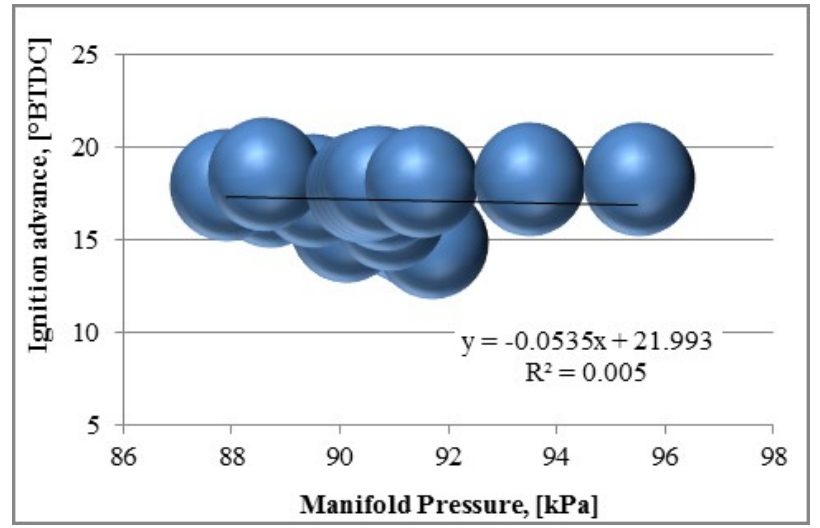

Fig. 18. Injection advance versus manifold pressure.

Ignition advance increases with higher engine speeds as the fuel injection duty increases with throttle position and the pressing of the accelerator pedal.

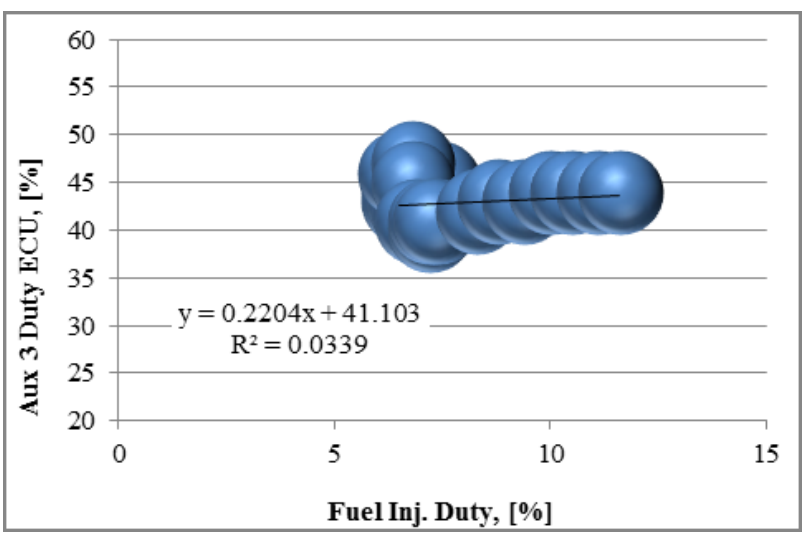

Fig. 19. Auxiliary duty in relation to the fuel injection.

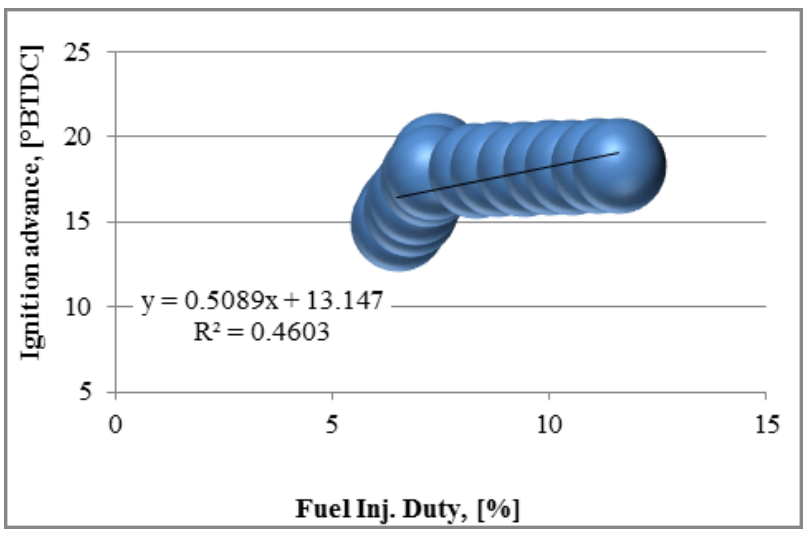

Fig. 20. Ignition advance versus fuel injection duty.

The experimental testing was conducted on a Mitsubishi rally car with technical spec details which are offered in Table 1.

Table 1. Tested vehicle's technical specifications.

\begin{tabular}{|c|c|c|c|}
\hline Variable & Value & UM & Obs. \\
\hline Model Y. & 2008 & year & operational \\
\hline Body code & CT9A & - & producer \\
\hline Engine & 2000 & $\mathrm{~cm}^{3}$ & - \\
\hline Gear box & 6-speed & ratios & manual \\
\hline Wheelbase & 2624 & $\mathrm{~mm}$ & adjusted \\
\hline Length & 4490 & $\mathrm{~mm}$ & - \\
\hline Width & 1770 & $\mathrm{~mm}$ & - \\
\hline Height & 1452 & $\mathrm{~mm}$ & adjusted \\
\hline Weight & 1355 & $\mathrm{~kg}$ & adjusted \\
\hline
\end{tabular}

Analyzing the actual or real values and specific trend-lines of the measurements recorded facilitated conclusive ideas, observations and interpretations.

\section{Conclusion}

The applied technical research has considered the operation of a rally ICE configured for a real power-train with multiple stresses. Fuel supply system with hydraulic and intake air manifold, software and electrically controlled valves, as well as and smart features and maps in operational management allowed the research to undertake the study of interfaces and correlations 
between mixture formation and ignition advance parameters as functions of the engine speed and throttle position.

The pick ignition advance angle (at $19^{\circ} \mathrm{BTDC}$ ) was determined for the $46 \%$ throttle position. In this point the lambda coefficient was 1.723. Air intake manifold pressure of the engine was almost $96 \mathrm{kPa}$ in the same point. A maximum of $12 \%$ fuel injection duty was recorded for the pick of the throttle position stored. The lowest spark ignition advance angle was found for the $0 \%$ throttle position with $91 \mathrm{kPa}$ intake air manifold pressure.

The maximum manifold pressure (at $95.8 \mathrm{kPa}$ ) was determined for the $46 \%$ throttle position and $18.5^{\circ} \mathrm{BTDC}$ ignition advance, while the minimum intake air manifold pressure was determined for the 17.9 ignition advance.

The minimum fuel injection duty was found at the $14.7^{\circ}$ BTDC ignition advance, meanwhile the highest fuel injection duty was recorded for the operating point at $18.2^{\circ} \mathrm{BTDC}$ ignition advance.

This experimental research in mechanic's field of control has developed the practical testing and data acquisition methodology from the fuel injection system with ECU and OBD interface recording actual values from the rally cars in operation. An innovation in the hydraulic and electronically operated injection system was achieved through computer aided testing and accurate analyze. The study was developed to predict the trend-lines of hydraulic dynamics and ignition advance. Injection system parameters are represented to understand complete interactions for efficiency improvement in the real working conditions.

Innovative map and strategy to optimize hydraulic injection systems for specific national rally competition may be defined by the application of a designed solution for electro-hydraulic interface interactions in mechanical control, such as ignition advance angle and fuel injection duty. Engine's map with injection data is important and offers adapted responses to the port fuel spray actuation. It generates a better quality of air-fuel mixture and thus leads to improved combustion sequence. This must be close studied and precisely tuned.

The model vehicle tested and studied was an operational integral system used in rally competitions in the national championship contest. It is a fully functioning model and during the recorded interval it worked perfectly for the defined objective.

The practical tests data showed an improved economy and output performances in real conditions (recorded in a particular working scenario at $14.7^{\circ}$ BTDC ignition advance) determining the lowest fuel amount injected close to the intake port. This facilitates higher heat release ratio in given time compared to the $\approx 19^{\circ}$ BTDC operation regime. It has an improved average performance and may predict lower emissions also. Creating the optimal working protocol with the lowest energy investments and wear, through the trendline and mathematical equations means innovating the operational control. Remapping would also be considered as ECU tuning alternatives in the future studies.

\section{References}

1. R. Basshuysen, Gasoline Engine with Direct Injection. Processes, Systems, Development, Potential, Vieweg+Teubner, GWV Fachverlage $\mathrm{GmbH}$, ISBN 978-3-8348-0670-3, Wiesbaden, (2009)

2. D. Băldean, N.V. Burnete, D. Moldovanu, F. Gaspar, A.I. Borzan, M.A. Crişan, Experimental Research Regarding the Possibility of Biofuel Fumigation Supply Method on a Single Cylinder Compression Ignited Engine, Proceedings of the conference CONAT- Paper presented at the 12th International Congress of Automotive and Transport Engineering CONAT-2016, A. Chiru \& N. Ispas, pp. 264-273, ISBN 978-3-319-45446-7, Brasov, Romania, October 26-29, Springer (2016)

3. N.Bățaga, et al Internal combustion engines/Motoare cu ardere internă, Editura Didactică și Pedagogică, ISBN 973-30-4922-0, București (1995)

4. N. Cordoş, et al. Automobiles. Construction. Wear. Evaluation/Automobile. Construcţie. Uzare. Evaluare, Ed. Todesco, ISBN 973-99779-7-9, ClujNapoca (2000)

5. I. Ferenți, D. Băldean, Artificial intelligence implemented in rally vehicles pentru increasing energetic efficiency in competitions/Inteligența artificială implementată în autovehicule de raliuri pentru creșterea eficienței energetice în competiții, https://stiintasiinginerie.ro/34-18-inteligentaartificiala-implementata-in-autovehicule-de-raliuripentru-cresterea-eficientei-energetice-in-competitii/, Mai 29, 2018. Accessed June 3 (2018)

6. I. Ferenți, D. Băldean, The analize of specific parameters for spark ignited engine operational cycle depending on altitude/Analiza mărimilor specifice ciclului funcțional al unui motor $\mathrm{cu}$ aprindere prin scânteie în raport cu altitudinea, $\mathrm{http}$ //stiintasiinginerie.ro/26-46-analiza-marimilorspecifice-ciclului-functional-al-unui-motor-cuaprindere-prin-scanteie-in-raport-cu-altitudinea/, January 31, 2015. Accessed June 3 (2018)

7. I. Ferenți, D. Opruța, D. Băldean, Analysis of Intelligent Control and Interface in Pressurized Liquid Injection Systems for Competitive Technical Solutions, http://hidraulica.fluidas.ro/2018/nr2/4348.pdf, Magazine of Hydraulics, Pneumatics, Tribology, Ecology, Sensorics, Mechatronics, ISSN 1453-7303 "HIDRAULICA" (No. 2/2018). Accessed July 3, 2018. 